\title{
Slaughterhouse Study on the Prevalence and Pathological Lesions Caused by Dictyocaulus Viviparus Infection in Cattle and Water Buffaloes
}

\author{
Keivan Jamshidi ${ }^{1 *}$, Afshin Zahedi ${ }^{2}$, Alireza Seidavi ${ }^{3}$, Mohammadreza Poorghasemi $^{3}$
}

1. Department of Veterinary Pathology, Faculty of Veterinary Medicine, Garmsar Branch, Islamic Azad University, Garmsar, Iran

2. Department of Veterinary Pathology, Faculty of Veterinary Medicine, Rasht Branch, Islamic Azad University, Rasht, Iran

3. Department of Animal Science, Faculty of Agriculture, Rasht Branch, Islamic Azad University, Rasht, Iran

\section{ABSTRACT}

Background: Dictyocaulus Viviparus nematode is the cause of severe bronchitis in dairy animals which lead to significant economic losses in the industry of this type of livestock. The present study aimed to determine the incidence of $D$. viviparous, a highly endemic parasite in cattle and water buffaloes in Guilan province, Iran.

Materials \& Methods: Stool samples from 212 cows and 189 buffaloes were tested using the Baermann technique. After slaughtering the animals, the lungs of all cows and buffaloes were isolated, sampled and carefully studied to determine $D$. viviparus in the lungs.

Results: In general, there was a significant difference in the prevalence of $D$. viviparus in the fecal samples of cows (22.64\%) and buffaloes (26.32\%). Macroscopic study revealed symptoms of severe pneumonia, nodular lesions, and hyperemia in lung tissues of 5 cows and 5 buffaloes. Microscopic (histopathological) studies showed lymphocytic bronchiolitis and multifocal eosinophilic with wide interalveolar walls in lungs infected with $D$. viviparus.

Conclusion: The prevalence of this parasite among cattle and buffaloes were $22.64 \%$ and $26.32 \%$, respectively; but the difference between these two animal species was not significant. Overall, the prevalence of $D$. viviparus was higher among young animals in both species.

Keywords: Water Buffalo, Cattle, Nematode, Dictyocaulus Viviparus, Lung, Pathology

Received: 2020/04/25; $\quad$ Accepted: 2020/08/26; Published Online: 2020/09/26

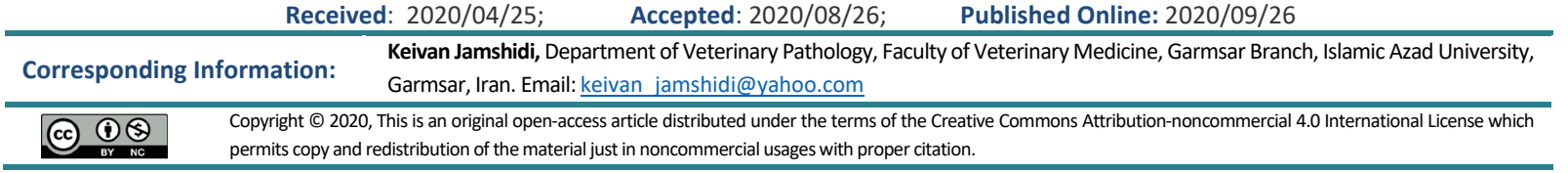

Use your device to scan and read the article online

Jamshidi K, Zahedi A, Seidavi A, Poorghasemi M. Slaughterhouse Study on the Prevalence and Pathological Lesions Caused by Dictyocaulus Viviparus Infection in Cattle and Water Buffaloes. Iran J Med Microbiol. 2020; 14 (6): 584-595

\section{Download citation: BibTeX | RIS | EndNote | Medlars | ProCite | Reference Manager | RefWorks}

Send citation to: $8 \underline{\text { Mendeley }} 2$ zotero $\overline{\mathrm{H}}$ RefWorks

\section{Introduction}

Livestock breeding plays an important role in the economy of villages in Guilan province in Iran and it is known as the only source of income for the rural middle class people in this province. Despite the existing problems, livestock breeding in this province is increasingly high and plays a significant role in the national economy (1). The dairy industry always suffers from various diseases, and among them, parasitic diseases and infections are of special importance since they impede the development of the dairy industry (2).

In the livestock industry, under some circumstances, such as low production for unknown reasons, high cost of treatment and workforce, and various parasitic diseases, the extermination of animals is inevitable (3). Control of various parasitic diseases is of the utmost importance in 
reducing costs and production-related disorders. Different parasitic infectious agents are known to be the cause of respiratory diseases in the livestock population. However, Dictyocaulus Viviparus has been identified as a potentially growing and costly problem (4) and the cause of parasitic pneumonia $(5,6,7)$. Lungworm (D. viviparus) is a relatively common parasite in tropical and subtropical regions and is the cause of economic losses to the livestock industry. This parasite causes severe lung diseases in cattle, commonly referred to as parasitic bronchitis, D. viviparus, or husk (8). Infected herds, depending on the degree of pasture contamination, usually show a high incidence of disease and mortality (9). Clinical signs in naturally infected animals include decreased appetite and growth, increased respiration and cough (10).

D. viviparus is known as a parasite that causes high mortality in cattle (11). Healthy animals become infected by eating contaminated forage. Chronic inflammatory changes in the animal's lungs include loss of ciliated epithelial cells, peribronchiolitis, eosinophilic bronchiolitis and atelectasis (12). In Iran, nematode infections in sheep and goats have been reported frequently $(13,14,15)$. However, there is limited information on the natural occurrence of $D$. viviparus infection and its pathology in native cattle and buffaloes. Therefore, the present study was designed to identify the incidence and frequency of macroscopic lesions and histopathology of infection with D. viviparus in dairy cattle and buffalos slaughtered in Rezvanshahr slaughterhouse in Iran.

\section{Materials and Methods}

In Rezvanshahr city, cattle and buffaloes are mainly kept in small groups (less than 10 heads) in rural areas. Dairy cattle are usually fed in a closed system using straw and concentrate, while younger animals graze on newly harvested farmland, around water canals and roadsides. Manual feeding and grazing of animals often take place throughout the year.

This research was conducted in 2018 and the inclusion criterion was the presence of cows and buffaloes infected with $D$. viviparus in the slaughterhouse. First, 189 male bulls and 212 male cows in Rezvanshahr slaughterhouse were examined for the infection of $D$. viviparus parasite in the feces. Bulls $(n=140)$ and cows $(n=95)$ were divided into 3 groups: less than 1 year old, 1-3 years old, and more than 3 years old. Similarly, all bulls $(n=125)$ and cows $(n=85)$ were classified into 3 age groups.

\section{Stool Test}

About $25 \mathrm{~g}$ of fresh feces were taken from the rectum of each animal before slaughter. The samples were stored at room temperature in the laboratory. Parasite eggs were identified using the Baermann technique and studied under a microscope (13).

\section{Macroscopic and Histopathological Studies}

After slaughter, all animals were studied one by one for the presence of lesions in the lungs. Finally, 5 lungs belonging to 5 buffaloes and 5 lungs belonging to 5 cows with symptoms of severe pneumonia, nodular lesions in the lung and hyperemia were identified and selected. The trachea, bronchi, and bronchioles of the animals were carefully dissected and examined for adult lungworms. Damaged lung tissue was treated with $10 \%$ stabilized neutral formalin buffer by conventional dewatering and immersion in paraffin. Then, tissue sections with a thickness of 4-5 microns were prepared and finally stained by hematoxylin and eosin (H\&D) method and studied under a light microscope (16). Microscopic lesions were examined and scored using a method previously proposed by Jung et al. (2012) (17).

\section{Data Analysis}

The collected data in the present study were analyzed using Chi-square test method with about 95\% confidence using SPSS software version 16 (SPSS Inc., Chicago, IL., USA).

\section{Results}

In the present study, the overall prevalence and infection of $D$. viviparus was recorded as $20.2 \%$, while the prevalence of this parasite among buffaloes and cows were $26.32 \%$ and $22.64 \%$, respectively. However, the difference between the two animal species was not significant. Overall, the prevalence of $D$. viviparus was higher among young animals in both species. The results are presented in detail in Table 1.

Table 1. Prevalence of Dictyocaulus viviparous infection in fecal samples of cows and buffaloes

\begin{tabular}{|c|c|c|c|c|c|c|}
\hline & & & Number of cattle & Number of positive & Pet. & \\
\hline \multirow{3}{*}{ Cow } & \multirow{3}{*}{212} & Under 1 year & 102 & 28 & 27.45 & \multirow{3}{*}{$22.64 \%$} \\
\hline & & Between 1-2 years & 48 & 8 & 16.66 & \\
\hline & & Over 2 years & 62 & 12 & 19.35 & \\
\hline \multirow{3}{*}{ Buffalo } & \multirow{3}{*}{189} & Under 1 year & 91 & 23 & 25.27 & \multirow{3}{*}{$26.32 \%$} \\
\hline & & Between 1-2 years & 42 & 3 & 7.14 & \\
\hline & & Over 2 years & 56 & 7 & 12.5 & \\
\hline Total & 401 & & 401 & 81 & 20.2 & \\
\hline
\end{tabular}


Under macroscopic examination, the lungs of infected cows and buffaloes showed nodular appearance, hyperemia, pleural adhesion, and purulent exudate (Table 2). Adult cylindrical worms were abundant within the upper posterior bronchi and within the terminal branches of the posterior bronchioles. The lungs were stiff and foamy exudates were visible in the bronchi.

Table 2. Periodicity of lung lesions due to Dictyocaulus Viviparus in cows and buffaloes

\begin{tabular}{|c|c|c|c|c|}
\hline \multirow{2}{*}{ Lesions } & \multicolumn{2}{|c|}{ Buffalo } & \multicolumn{2}{|c|}{ Cow } \\
\hline & Number & Pct. & Number & Pct. \\
\hline \multicolumn{5}{|l|}{ Macroscopic } \\
\hline Hyperemia & 3 & 60 & 2 & 66.6 \\
\hline Foam in the trachea & 1 & 20 & 0 & 0 \\
\hline Stiffness of lung & 2 & 40 & 1 & 33.33 \\
\hline Nodular & 4 & 80 & 3 & 100 \\
\hline Pleural adhesion & 0 & 0 & 1 & 33.33 \\
\hline Pleural exudation & 1 & 20 & 1 & 33.33 \\
\hline Parasites in the bronchioles & 2 & 40 & 0 & 0 \\
\hline \multicolumn{5}{|l|}{ Histopathological } \\
\hline $\begin{array}{l}\text { Stages of parasitic growth and development (eggs / larval } \\
\text { stage L1, adult) }\end{array}$ & 4 & 80 & 2 & 33.33 \\
\hline Accumulation of mononuclear cells & 5 & 100 & 3 & 0 \\
\hline hyperemia & 3 & 60 & 2 & 66.66 \\
\hline Peribronchial fibrosis & 4 & 80 & 0 & 0 \\
\hline Alveolitis & 4 & 80 & 0 & 0 \\
\hline Peribronchiolar cuffing & 3 & 60 & 1 & 33.33 \\
\hline
\end{tabular}

Histopathological studies showed an abundance of exudates within the bronchioles, which mainly contained eosinophils, lymphocytes, macrophages, and giant cells. Degenerative and necrotic changes were observed in the epithelium of bronchioles. Some histopathological

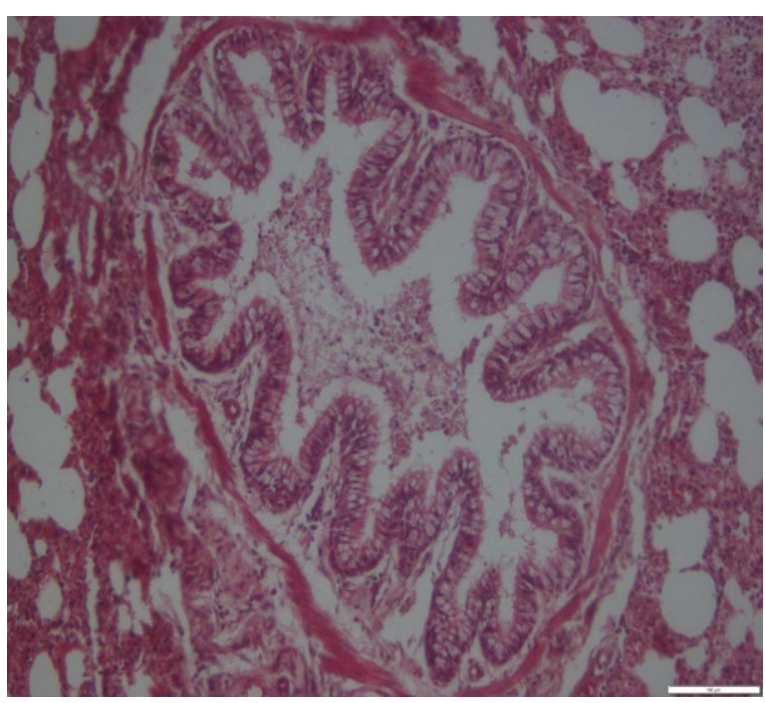

Figure 1. Cow lung. Bronchioles. Hyperplasia of goblet cells an epithelial cells with exudate containing inflammatory cells. H\& coloring. Magnification 4. sections showed catarrhal bronchiolitis and atelectatic changes along with alveolitis granulomatosis and specific eosinophilic. Hyperplasia of goblet cells and lymphoid tissue around the bronchioles were also observed (Figures 1, 2, 3, and 4).

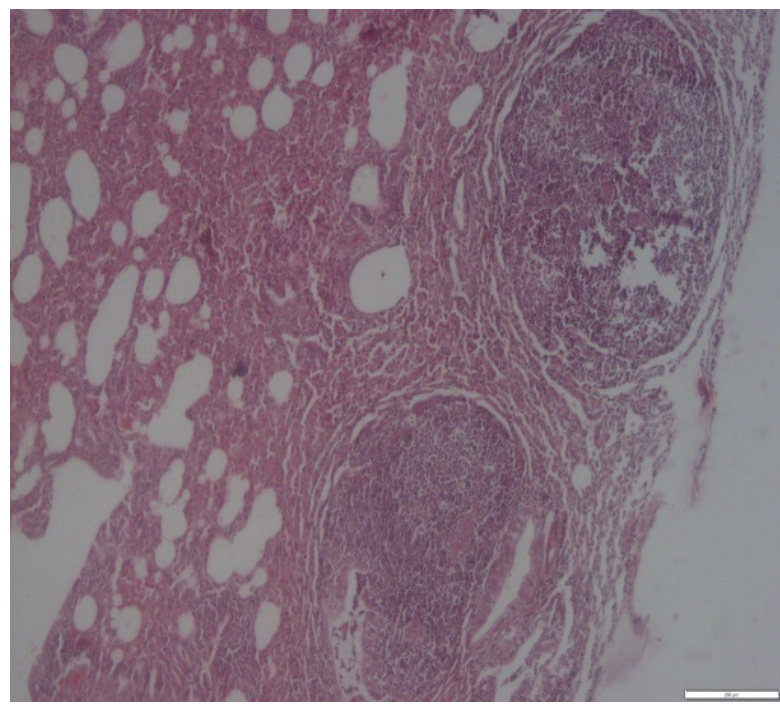

Figure 2. Buffalo lung. Granulomatous alveolitis and atelectati changes. H\&E coloring. Magnification 4. 


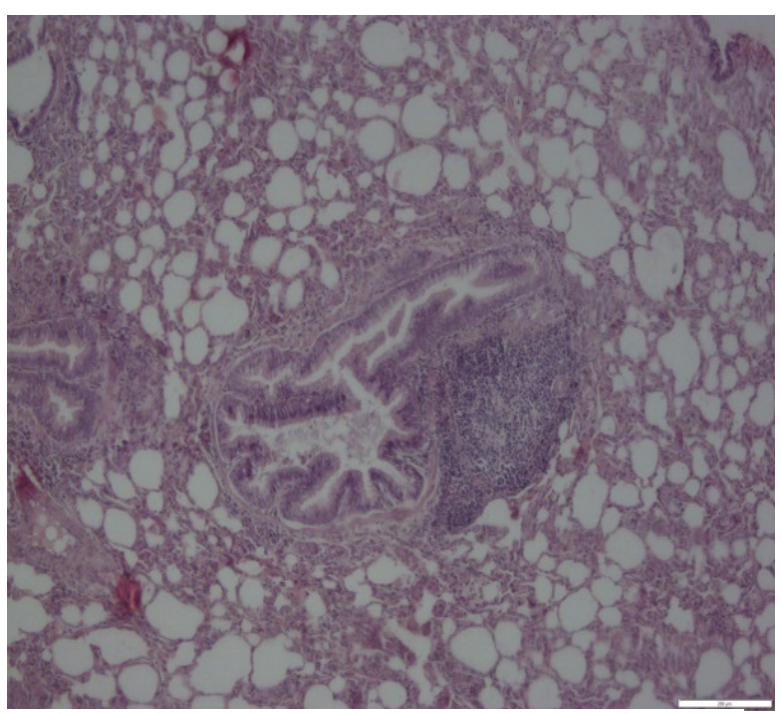

Figure 3. Buffalo lung. Bronchioles. Hyperplasia of goblet cell and lymphoid tissue around the bronchioles. H\&E coloring Magnification 4.

Egg clusters, freshly hatched larvae were observed in the alveoli, and rupture of the inter-alveolar wall in the lungs of cattle and buffaloes. The inter-alveolar

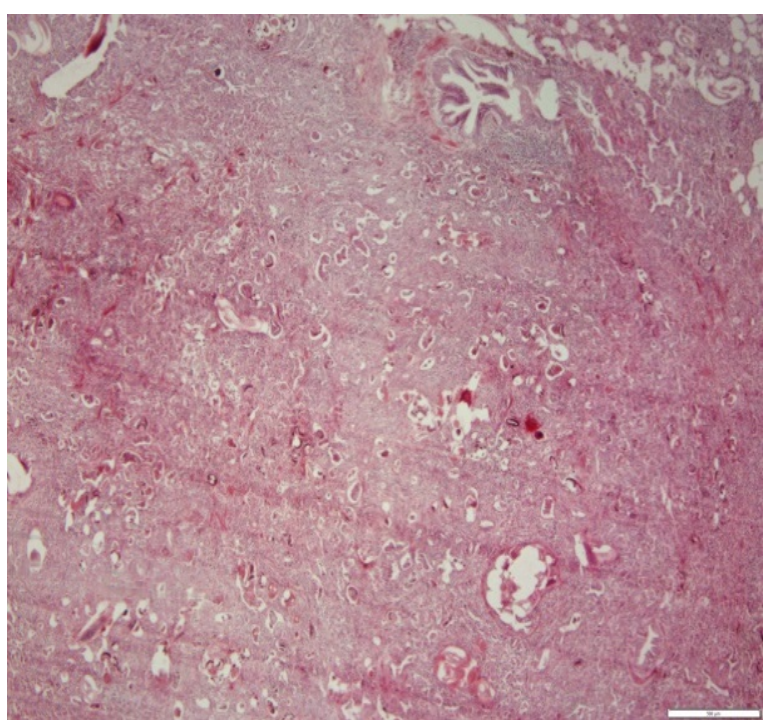

Figure 5. Cow lung. Note the presence of larval and egg section of the parasite in the respiratory tract, cellular exudate withi the ducts and alveoli, and thickening of the wall between th alveoli. H\&E coloring. Magnification 4.

\section{Discussion}

Previously, the prevalence and infection (34-8\%) with $D$. viviparus parasite in various dairy herds and sheep in different climatic regions of different countries had been reported $(18,19,20)$. Heavy rains during hot and humid seasons are suitable for the survival of infectious nematode larvae in green forage pastures that support the growth and development of these nematodes and the greater chance of being eaten by cattle and buffaloes.

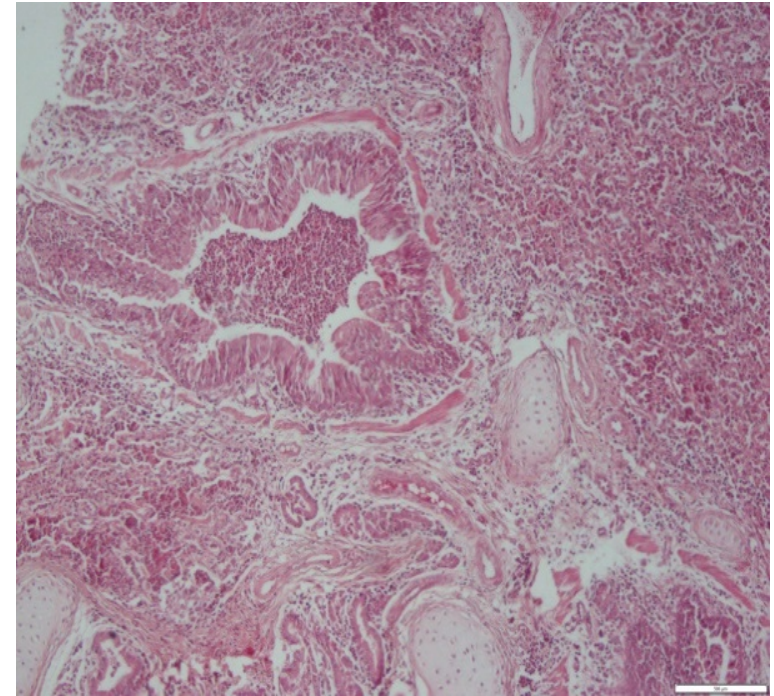

Figure 4. Cow lung. Bronchus. Exudates of inflammatory an neutrophil-rich cells within the bronchial canal and alveoli. H\& coloring. Magnification 4

walls were thickened due to inflammatory cell infiltration, mild fibroplasia, and proliferation of type II pneumonocytes (Figures 5 and 6).

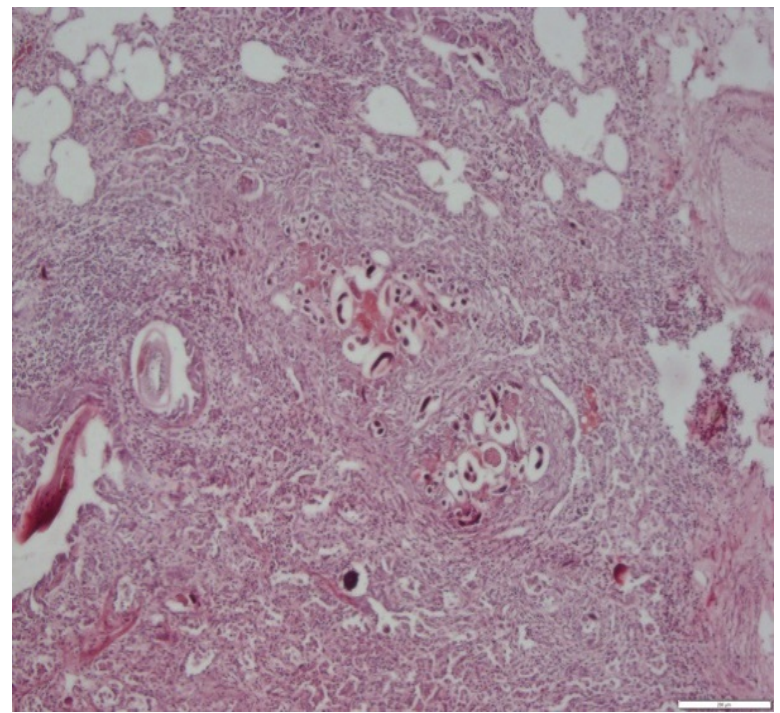

Figure 6. Buffalo lung. Note the presence of larval and eg sections of the parasite in the respiratory tract, cellular exudat within the ducts and alveoli, and thickening of the wall betweel the alveoli. H\&E coloring. Magnification 4.

Although infection with $D$. viviparus has been reported from tropical and sub-tropical countries such as Brazil (21), India (22), Malaysia (23), and Turkey (10), countries with a temperate climate, such as Ireland (24), Germany (25), the Netherlands (4), and Sweden (26) are not free of this parasite. Lungworm infection has also been reported among wildlife animals such as roe deer and cervids $(27,28)$.

In the present study, the prevalence of $D$. viviparus infection in young animals was insignificantly higher 
$(P>0.210)$ (Table 1$)$. The reason can be explained by the fact that older animals have grown immunity to the disease and do not repel nematode larvae $(29,30)$.

Different developmental stages of the parasite, including newly hatched larvae of $D$. viviparus, have also been reported in ruminants (31). In the present study, chronic inflammatory cells and increased connective tissue proliferation were observed in infected lungs. Loss of bronchial ciliated epithelial cells was observed along with inflammatory cells infiltration and formation of lymphoid follicles around the bronchioles. These pulmonary changes may be due to the proliferation of immunological cells in response to the proliferation of $D$. viviparus eggs and the migration of adult larvae into lung tissue (10).

Ploeger et al. (2002) reported that $D$. viviparus, the main etiologic cause of parasitic bronchitis in animals, is first swallowed as a larva and then penetrates the intestinal wall and then passes through the lymph nodes and migrates through the bloodstream to the lungs and becomes an adult worm (4). In the lungs, pathological changes occur due to the invasion and activation of eosinophils and mast cells, which lead to narrowing of the airways and cause edema, emphysema, and alveolar collapse (4). Similar changes have been reported in the lungs due to $D$. viviparus infection in cattle (25), sheep and goats (12), foal (32), deer calves (32), and Rocky Mountain elk (32).

\section{Conclusion}

There was no comprehensive study to determine the prevalence of $D$. viviparus infection in Iran's climate. The findings of the present study include useful information about the prevalence of $D$. viviparus nematode infection and its pathological findings in cattle and buffaloes. Therefore, more epidemiological and molecular studies are needed to identify the characteristics of this parasite in Iran.

\section{Acknowledgment}

The authors of this study would like to thank the experts of Rezvanshahr slaughterhouse and the head of the Microbiology Laboratory of the Islamic Azad University, Rasht Branch, who helped us in performing this research.

\section{Ethical considerations}

Ethical issues (Including plagiarism, informed consent, misconduct, data fabrication and/or falsification, double publication and/or submission, redundancy, etc.) have been completely observed by the authors.

\section{Funding and support}

This research resulted from an independent research without receiving any financial support.

\section{Conflict of Interest}

Authors declared no conflict of interests. 


$$
\begin{aligned}
& \text { مجله ميكروبشناسى يزشكى ايران } \\
& \text { سال If ـ شماره 9 ـ آذر و دى 999 } \\
& \text { Journal homepage: www.ijmm.ir }
\end{aligned}
$$

\title{
مطالعه كشتاركاهى ميزان شيوع و ضايعات پاتولوزيك ناشى از آلودكى به Dictyocaulus viviparous
}

\author{
كيوان جمشيدى ا"، افشين زاهدى '، عليرضا صيداوى " محمدرضا يورقاسمى
}

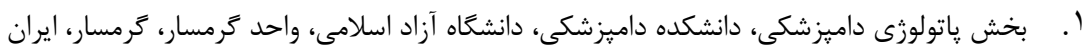

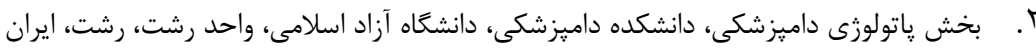

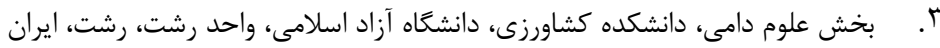

\section{جكيده}

زمينه و اهداف: نماتود Dictyocaulus viviparus عامل برونشيت شديد در حيوانات شيرى بوده و بهعنوان مسئول

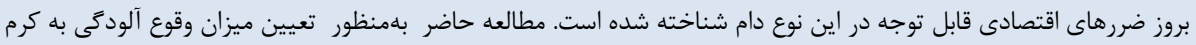

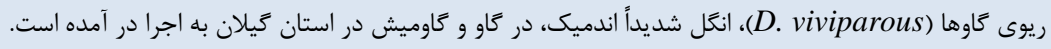

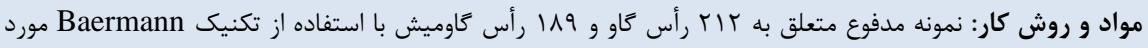

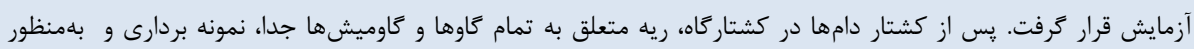

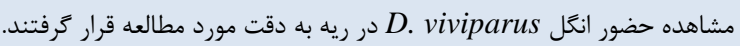

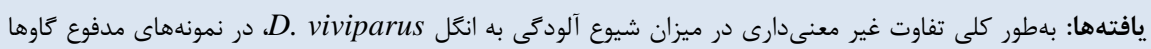

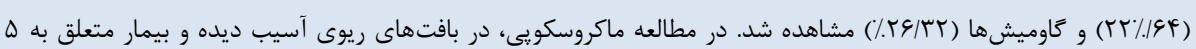

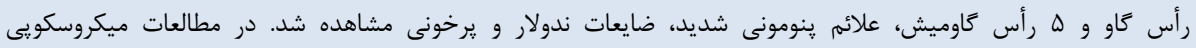

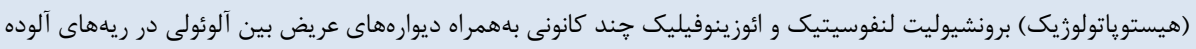
به D. viviparus مشاهده شد.

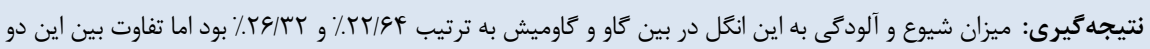

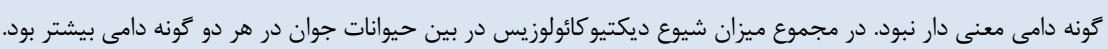
كليد وازهها: كاوميش، كاو، نماتود، ديكتيو كائولوس ويوى ياروس، ريه، باتولوزى
اطلاعات مقاله

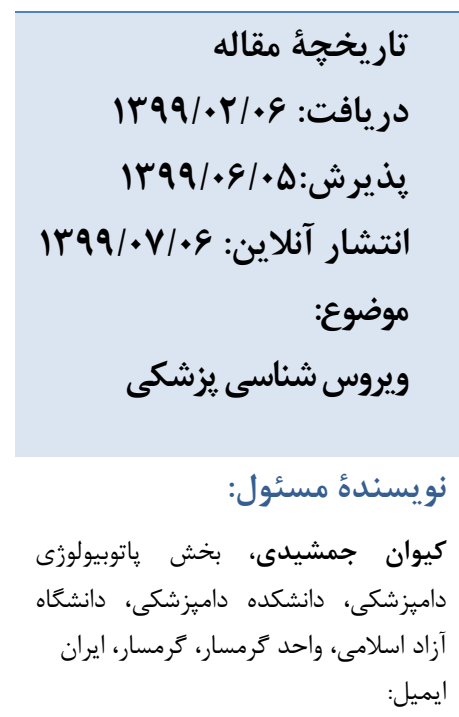

keivan_jamshidi@yahoo.com

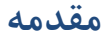

هزينه كارگرى، و بيمارىهاى انگلى متفاوت، حذف حيوانات امرى اجتنابنايذير خواهد بود (ب). كنترل بيمارىهاى انكلى متنوع حائز بالاترين اهميت در كاهش هزينهها و اختلالات توليد است. عوامل عفونى انگلى متفاوتى بلهعنوان مسئول بيمارىهاى تنفسى در جمعيت دامى شناخته شدهاند. باين حال، ديكتيوكولوزيس بلعنوان مسئول بيمارئ مسئله بالقوه فزاينده و يرهزينه

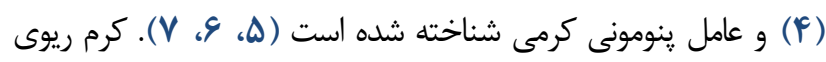
انكل نسبتاً شايع در مناطق كرمسيرى و نيمه (Dictyocaulus viviparus) كرمسيرى بوده و عامل ضرر و زيان اقتصادى وارد بر صنعت يرورش دام است. اين انكل بيمارى ريوى شديدى را در كاو بهوجود مى آورد كه عموماً
يرورش دام نقش مهمى در اقتصاد روستايى استان گيلان داشته و بهعنوان منبع خالص درآمد طبقات متوسط روستايى در اين استان شناخته شده است. على رغم مشكلات موجود، نَخهدارى و يرورش دام در اين استان رشد فزايندهاى داشته و نقش قابل توجهى را در اقتصاد ملى به خود اختصاص داده است (1). صنعت شير همواره از بيمارىهاى مختلفى رنج

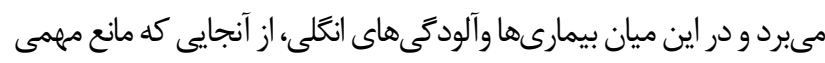

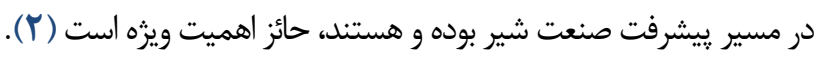
در صنعت يرورش دام، در برخى شرايط پيیجيده مانند كاهش توليد شير بدلايل نامشخص، افزايش هزينههاى درمان در هر بيمارى، افزايش 


\section{آزمايش مدفوع}

در حدود هץ گ گرم مدفوع تازه از از ركتوم هر حيوان ييش از ذبح اخذ شد. نمونههاى اخذ شده يس از انتقال به آزمايشعاه در دماى اتاق

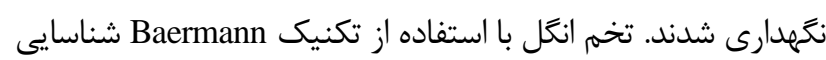
و زير ميكروسكوٍ مورد مطالعه قرار گرفت (سا).

\section{مطالعات ماكروسكويى و هيستوياتولوزى}

يس از ذبح تمام حيوانات (كاوميش= 1199 رأس و Fاو=

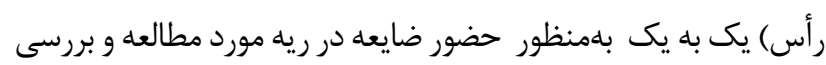

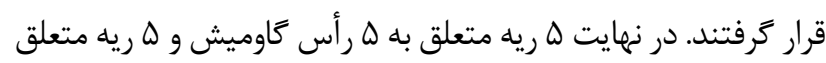

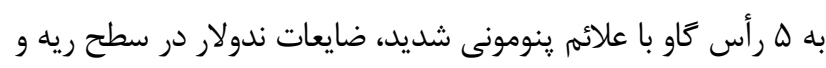

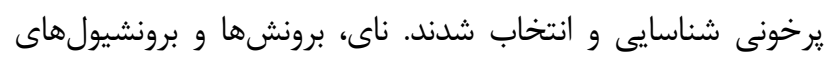
حيوانات بلهمنظور ييدا كردن كرمهاى ريوى بالغ به دقت شكافته و

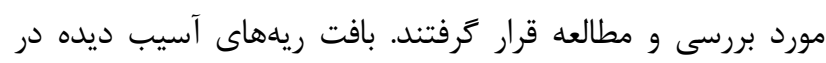

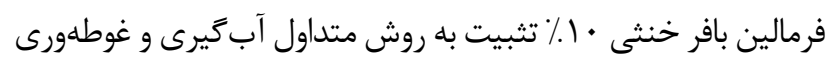

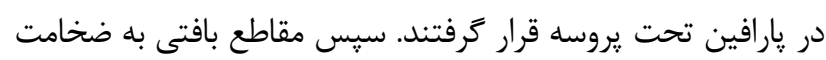

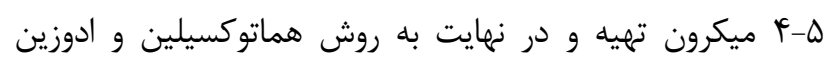
رنخَآميزى شده و زير ميكروسكوب نورى مورد مطالعه قرار گرفتند

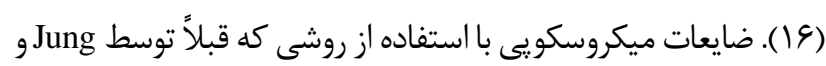

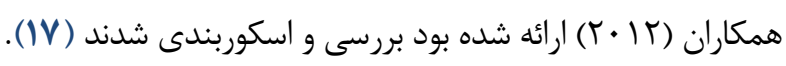

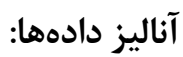

دادهاى جمعآورى شده در مطالعه حاضر با استفاده از روش SPSS با حدود هو درصد اطمينان با نرم افزار آمارى Chi-square test نسخئ 9 (SPSS Inc., Chicago, IL., USA) تجزيه و تحليل شدند.

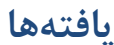

در مطالعه حاضر ميزان كلى شيوع و آلودگى به انگل Dictyocaulus viviparus

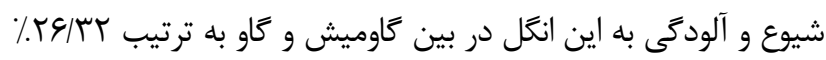

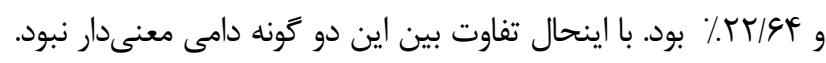

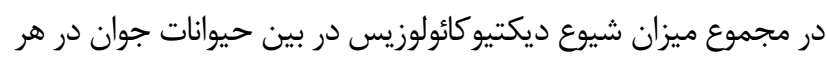
دو گونه دامى بيشتر بود. نتايج به تفصيل در جدول الريو دائه شده است. در معاينات ماكروسكويى، ريههاى گاوها و Fاوميشهاى مبتلاظاهر

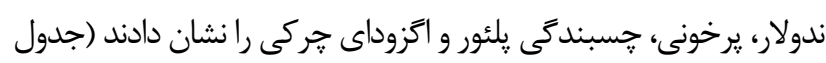

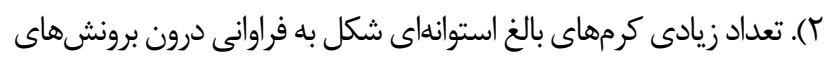
فوقانى خلفى و درون انشعابات انتهايى برونشيولهاى خلفى وجود داشتند. ريهها سفت بوده و اگزوداى كفآلود در برونشها قابل مشاهده بود.
تحت عنوان برونشيت انكلى، ديكتيوكائولوزيس يا هاسك (husk) ناميده

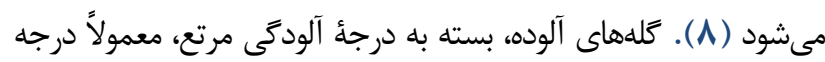

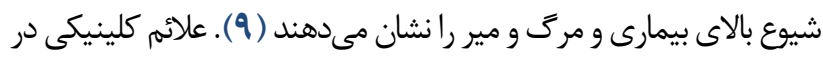

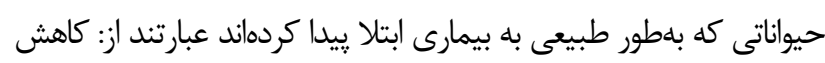
اشتها، كاهش رشد، افزايش تنفس و سرفه (•(1).

ديكتيو كائولوس وى وى ياروس (Dictyocaulus viviparus) بهعنوان انگلى كه عامل مرى و مير بالا در زاو مىباشد شناخته شده است (I). حيوانات سالم از طريق خوردن علوفه آلوده به

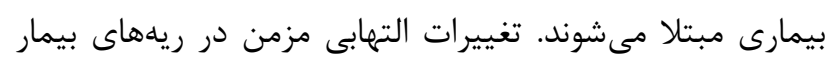
شامل از دست دادن سلولهاى إيتليوم مزكدار، يرى برونشيوليت،

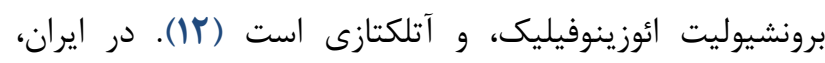
عفونتهاى نماتودى در گ گوسفند و بز به دفعات گزارش شده است

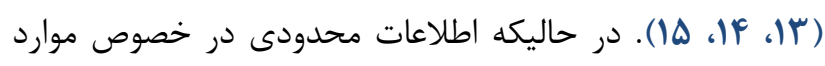
وقوع طبيعى آلودگى به Dictyocaulus viviparus و ياتولوزى آن

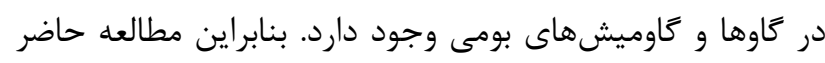
بهمنظور شناسايى ميزان وقوع و تناوب ضايعات ماكروسكويى و هيستوياتولوزى آلودىى و عفونت به Dictyocaulus viviparus در كاو و كاوميش شيرى ذبح شده در كشتار كاه شهرستان رضوان شهر طراحى و اجرا شده است.

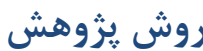

در شهرستان رضوان شهر، كاو و كاوميش عمدتاً در دستجات

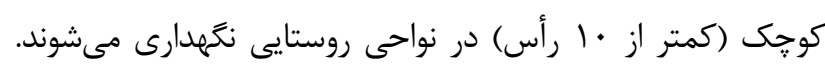
حيوانات شيروار معمولاً در يك سيستمم بسته و با استفاده از كاه و و

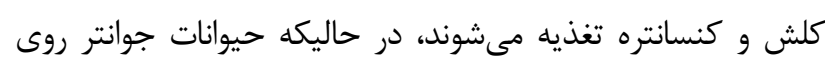
زمينهاى كشاورزى تازه درو شده، اطراف كانالهاى آب و حاشيه

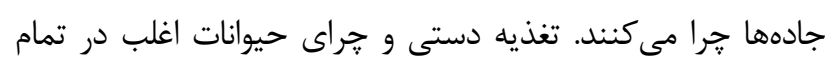
طول سال صورت مى گيرد.

اين تحقيق در سال Vq I انجام شد و معيار ورود آن وجود كاو و Fاوميش هاى مبتلا به انگل Diviparus در كر كشتاركاه بود.

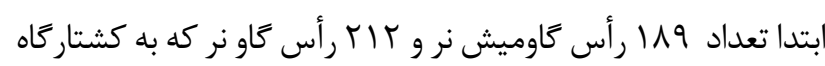

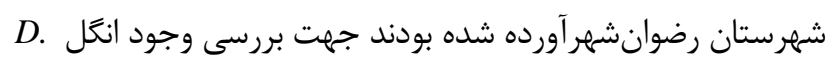
viviparus

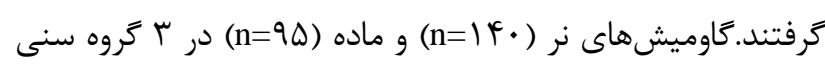

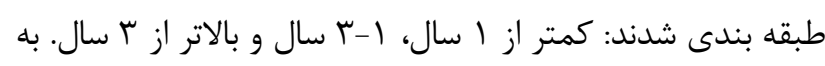

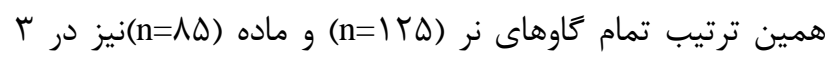
كروه سنى طبقه بندى شدند. 
جدول ا ـ ميزان شيوع آلودگى به انگًل Dictyocaulus viviparous در نمونه هاى مدفوع مطالعه و ثبت شده در گاو و كاوميش

\begin{tabular}{|c|c|c|c|c|c|c|}
\hline & درصد & تعداد مثبت & حداد دام & & & \\
\hline \multirow{3}{*}{ Tr\% $/ 19 F$} & $T V / F D$ & $r \Lambda$ & $1 \cdot r$ & زير ا سال & \multirow{3}{*}{ rir } & \multirow{3}{*}{ كاو نر } \\
\hline & 19198 & $\wedge$ & iA & بين ا تا r & & \\
\hline & $19 / \Gamma \Delta$ & ir & GT & بالاى r & & \\
\hline \multirow{4}{*}{ TE\% } & $r \Delta / T V$ & r & 91 & زير ا سال & \multirow{3}{*}{119} & \multirow{3}{*}{ كاوميش نر } \\
\hline & $V / l F$ & $r$ & Fr & بين ا تا r & & \\
\hline & $1 \pi / \Delta$ & v & $\Delta \varphi$ & بالاى r & & \\
\hline & $r \cdot / r$ & $\wedge 1$ & $r \cdot 1$ & & k.1 & جمع \\
\hline
\end{tabular}

جدول r. تناوب ضايعات ريوى بدليل Dictyocaulus viviparus در كاو و گاوميش

\begin{tabular}{|c|c|c|c|c|}
\hline \multicolumn{2}{|c|}{ 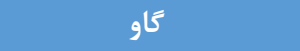 } & \multicolumn{2}{|c|}{ 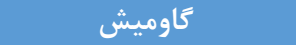 } & \multirow{2}{*}{ ضايعات } \\
\hline درصد & 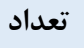 & درصد & تعداد & \\
\hline & & & & ماكروسكويى \\
\hline $99 / 9$ & r & c. & r & 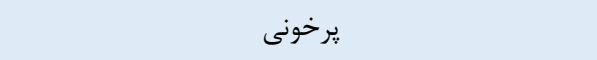 \\
\hline · & · & $r \cdot$ & 1 & كف درناى \\
\hline אז/זr & 1 & f. & r & سفت شدن قوام ريه \\
\hline $1 \cdots$ & r & $\wedge \cdot$ & r & سطح ندولار \\
\hline 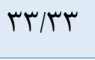 & 1 & • & · & جسبندگى يلئور \\
\hline א & 1 & $r \cdot$ & 1 & اگزوداسيون يلئور \\
\hline · & · & r. & r & وجود انخل در برونشيول \\
\hline & & & & هيستوياتولوزيك \\
\hline 99199 & r & $\wedge$. & f & مراحل رشد و تكامل انخلى (تخم/ مرحله لارو L1 ، بالغ) \\
\hline · & r & $1 \cdots$ & $\Delta$ & تجمع سلول هاى تك هسته اى \\
\hline 99199 & r & 4. & r & 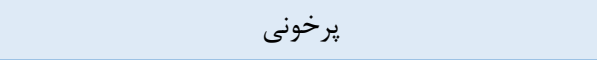 \\
\hline$\cdot$ & $\cdot$ & $\wedge \cdot$ & f & فيبروز پرى برونشيولى \\
\hline$\cdot$ & $\cdot$ & $\wedge$. & f & 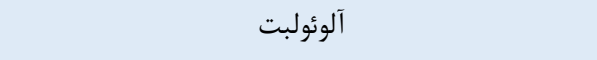 \\
\hline 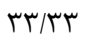 & 1 & 4. & r & Peribronchiolar cuffing \\
\hline
\end{tabular}

تغييرات آتلكتاتيك به همراه آلوئوليت كرانولوماتوز ائوزينوفيليك

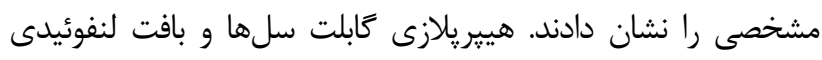

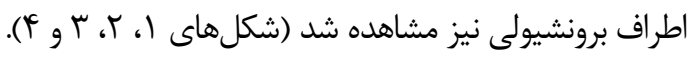

در مطالعات هيستوياتولوزيك اگزوداى فراوانى درون برونشيولها مشاهده شد كه عمدتاً حاوى ائوزينوفيلها، لنفوسيتها، ماكروفازها و و

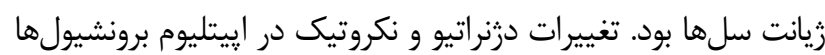

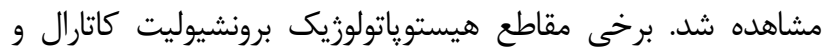




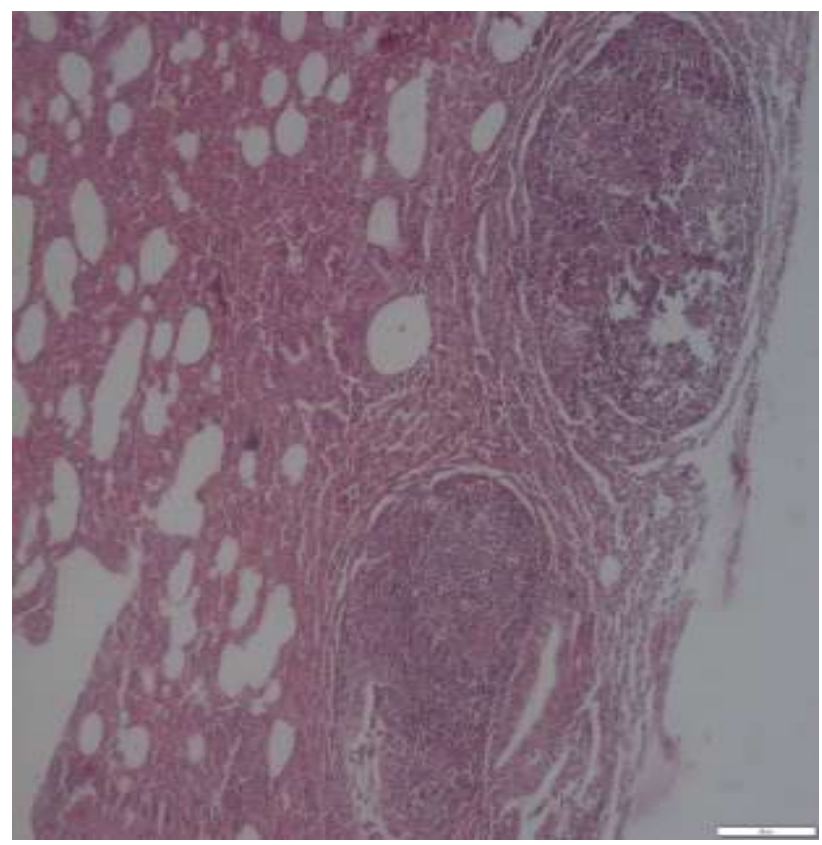

شكل r. ريه كاوميش. آلوئوليت كَانولوماتوز و تغييرات آتلكتاتيك.

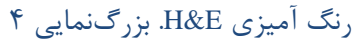

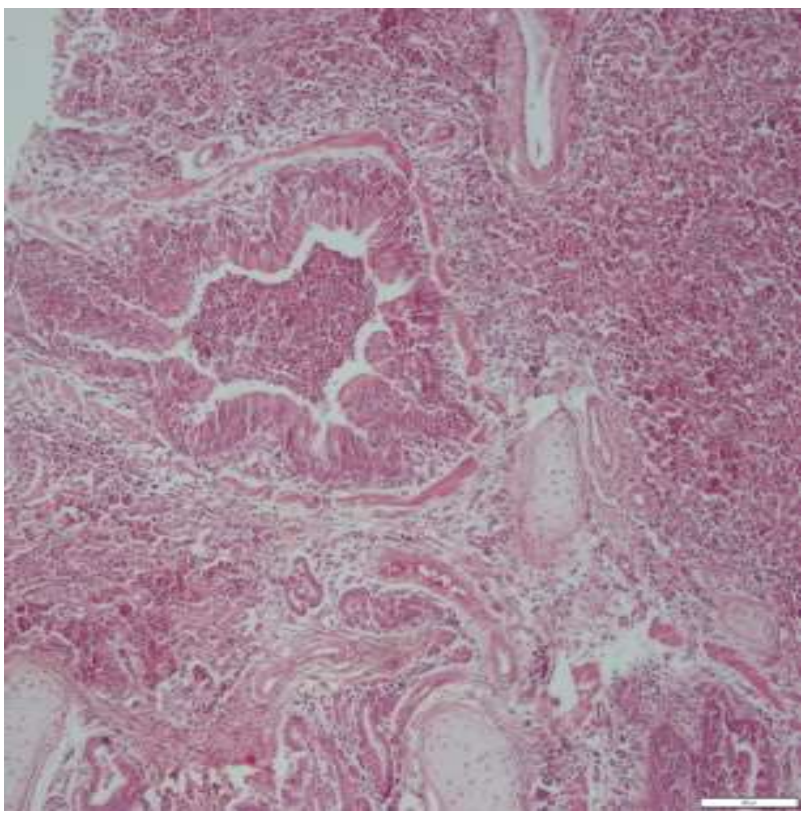

شكل F. ريه كَاو. برونش. حضور ازَوداى سلولهاى التهابى و غنى از

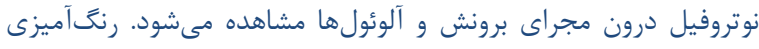
H\&E

فيبرويلازى ملايم و تكثير پينومونوسيتهاى تيب II ضخيم شده بودند (شكل هاى ه و و ().

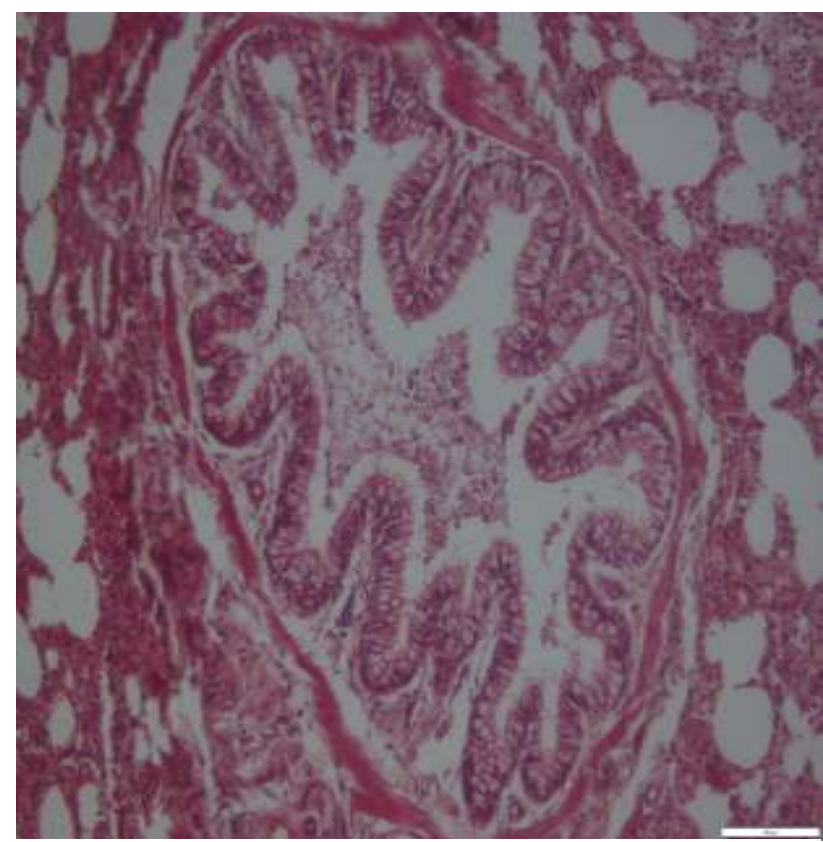

شكل ا. ريه گاو. برونشيول. هييريلازى كابلت سلها و سلولهاى

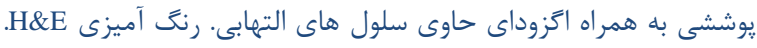

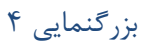

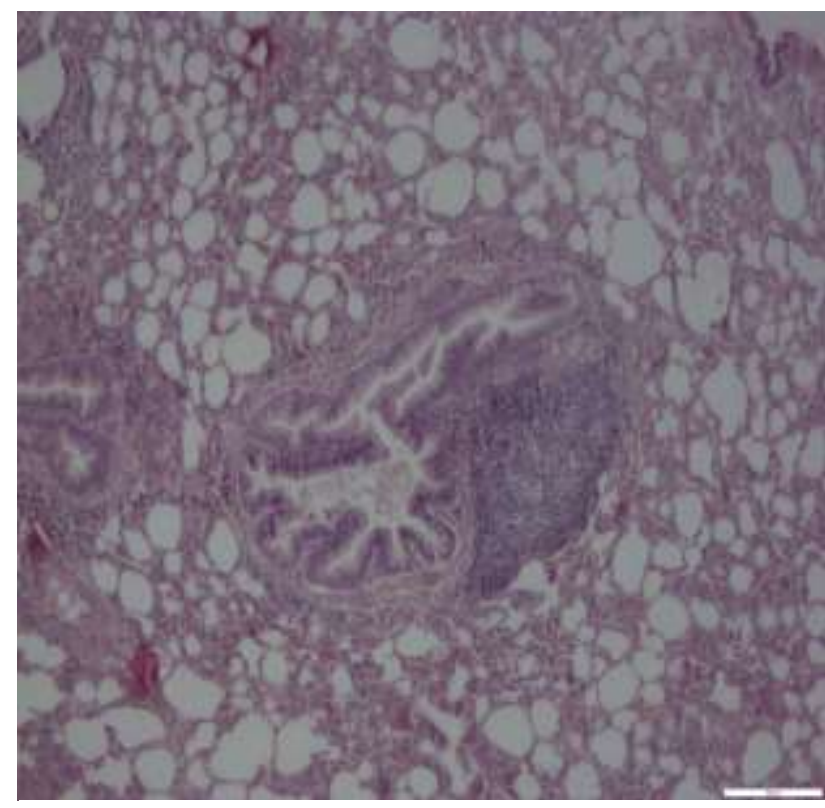

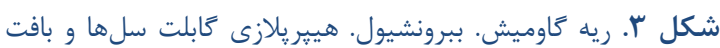

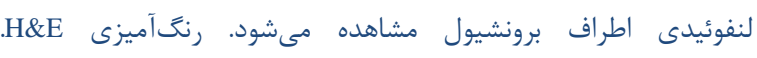

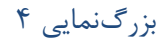

دستجات تخمها، لاروهاى تازه هج شده در آلوئولها و پاره

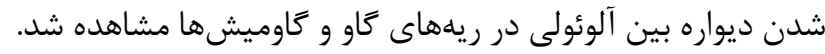

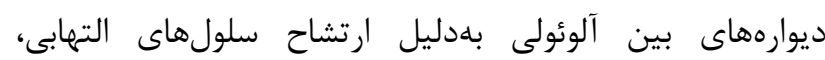




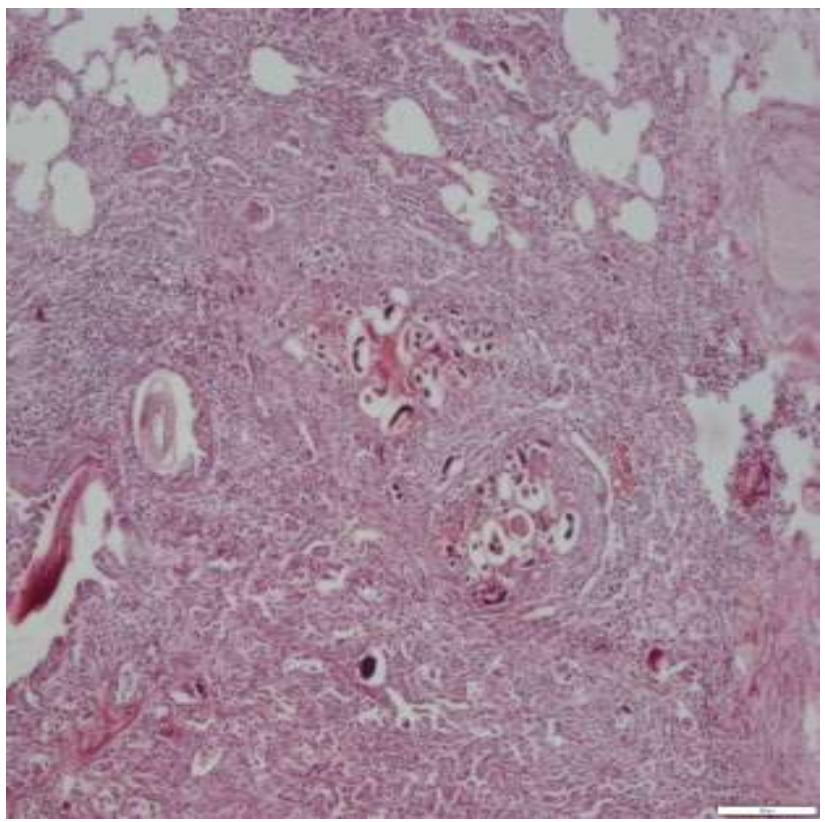

شكل \&. ريه كاوميش. به حضور مقاطع لارو و تخم انكل در مجارى

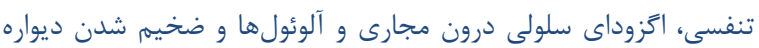

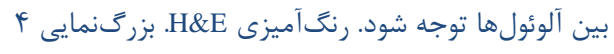

مراحل تكاملى متفاوت انكل شامل لاروهاى تازه هج شده Dictyocaulus viviparus

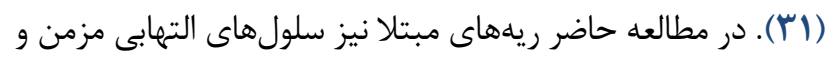

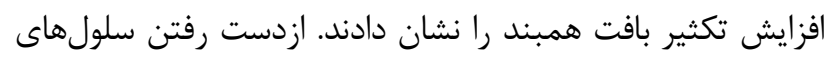
إيتليوم مزكدار برونشيولى به همراه ارتشاح سلولهاى التهابى و و

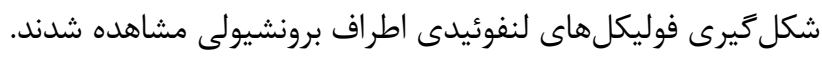

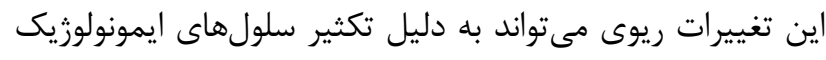

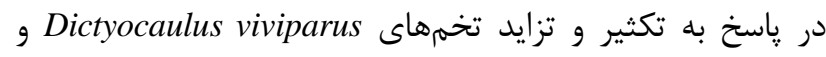
مهاجرت لاروهاى بالغ در بافت ريه باشد (•(1). و همكاران (Tloeger

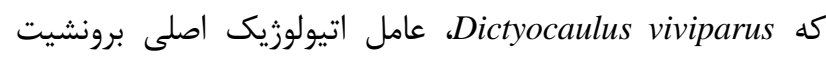

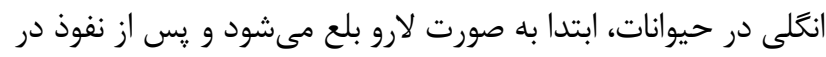

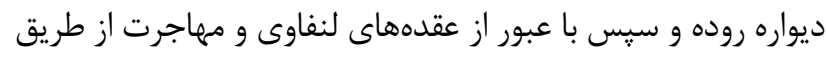

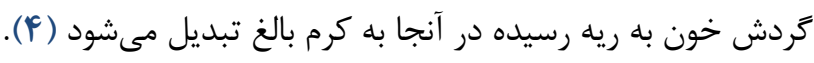

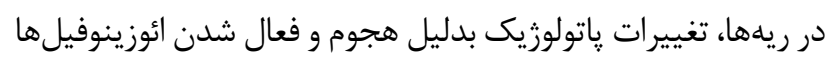

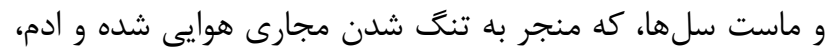

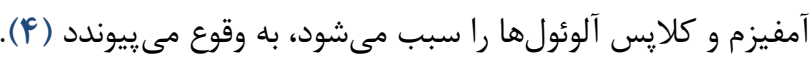

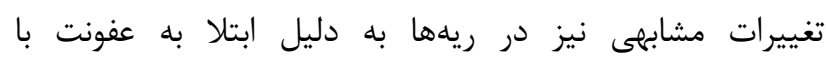
Dictyocaulus viviparus

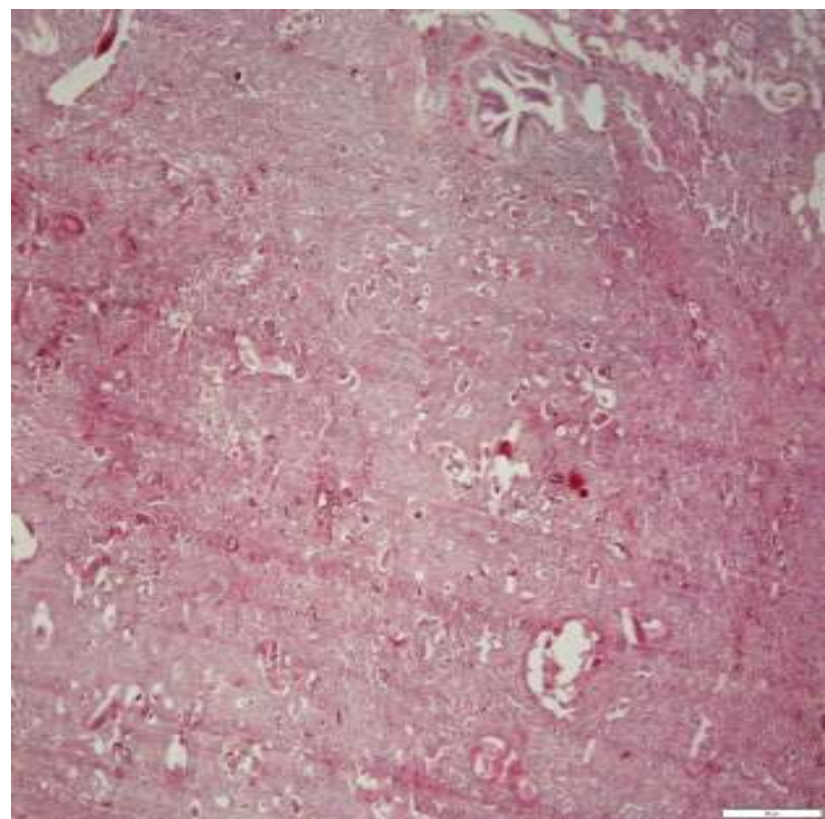

شكل ه. ريه كاو. به حضور مقاطع لارو و تخم انكل در مجارى تنفسى،

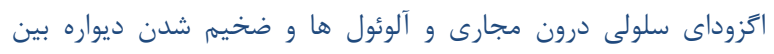

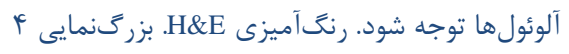

بحث

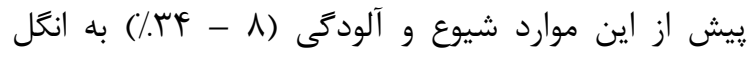
Dictyocaulus viviparus

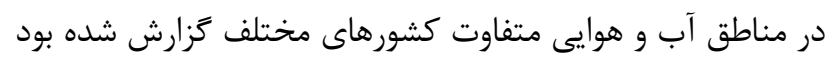

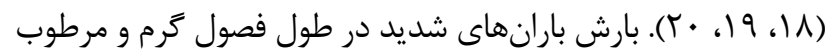

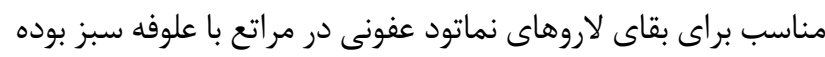

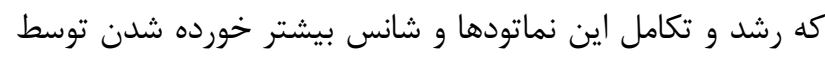
كاو و گاوميش را حمايت مى كند.

اگرجه آلودگى به Dictyocaulus viviparus از كشورهاى sub-tropical g tropical

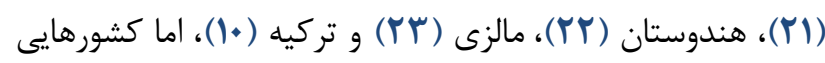

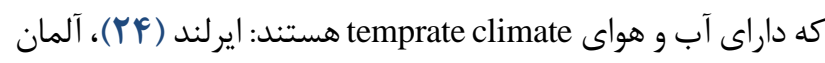

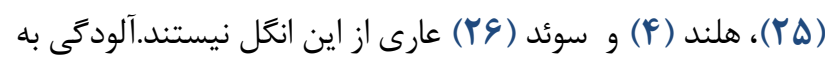

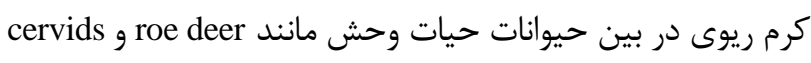

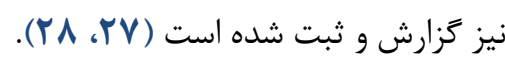

در مطالعه حاضر ميزان شيوع آلودگى به viviparus

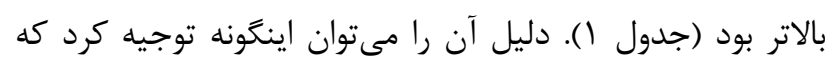

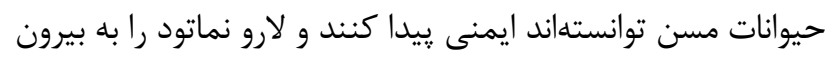

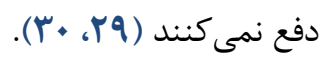




$$
\begin{aligned}
& \text { سياسگزارى } \\
& \text { بدين وسيله از كارشناسان محترم كشتارگاه رضوان شهر و } \\
& \text { مسئول آزمايشگاه ميكروبيولوزى دانشگاه آزاد اسلامى واحد رشت } \\
& \text { كه ما را در اجراى اين يزوهش يارى كردند، تقدير و تشكر مى شود. } \\
& \text { تعارض در منافع } \\
& \text { اين مقاله يزوهشى مستقل است كه بدون حمايت مالى } \\
& \text { سازمانى انجام شده است. در انجام مطالعئ حاضر، نويسندكان } \\
& \text { هيجزَّنه تضاد منافعى نداشتهاند. }
\end{aligned}
$$

\section{Referance}

1. Poorghasemi M, Chamani M, Mirhosseini SZ, Sadeghi AA, Seidavi A. Effect of probiotic and different sources of fat on performance, carcass characteristics, intestinal morphology and ghrelin gene expression on broiler chickens. Kafkas Univ Vet Fak Derg. 2017; 24(2): 169178.

2. Alim MA, Das S, Roy K, Masuduzzaman M, Sikder S, Hassan MM, et al. Prevalence of hemoprotozoan diseases in cattle population of Chittagong division, Bangladesh. Pak Vet J. 2012; 32: 221-224.

3. Khan MN, Rehman TU, Sajid MS, Abbas RZ, Zaman MA, Sikandar A, et al. Determinants influencing prevalence of coccidiosis in Pakistani buffaloes. Pak Vet J. 2013; 33: 287-290.

4. Ploeger HW, Borgsteede FH, Sol J, Mirck MH, Huyben MW, Kooyman FN, et al. Cross sectional serological survey on gastrointestinal and lung nematode infections in first and second-year replacement stock in the Netherlands: relation with management practices and use of anthelmintics. Vet Parasitol. 2002; 90: 285-304. [DOI:10.1016/S0304-4017(00)00246-6]

5. Zaman MA, Iqbal Z, Khan MN, Muhammad G. Anthelmintic activity of a herbal formulation against gastrointestinal nematodes of sheep. Pak Vet J. 2012; 32: 117-121.

6. Laabs EM, Schnieder T, Strube C. Transcriptional differences between hypobiotic and nonhypobioticpreadult larvae of the bovine lungworm Dictyocaulusviviparus. Parasitol Res. 2012; 110: 151-159. [DOI:10.1007/s00436-011-2464-7] [PMID]

7. Larsson A, Uggla A, Waller PJ, Höglund J. Performance of second-season grazing cattle following different levels of parasite control in their first grazing season. Vet Parasitol. 2011; 175: 135-140. [DOI:10.1016/j.vetpar.2010.09.018] [PMID]

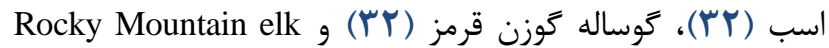

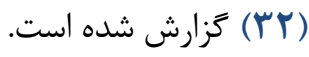

$$
\text { نتيجهَ }
$$

ييش از اين مطالعهاى جامع در جهت تعيين و شناسايى

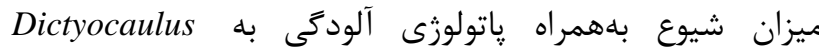
viviparus يافتهاى مطالعه حاضر شامل اطلاعات مفيدى در خصوص ميزان شيوع آلودگى به نماتود كرم ريوى Dictyocaulus viviparus و يافتههاى آسيبشناسى آن در كاو و كاوميش است. بنابراين

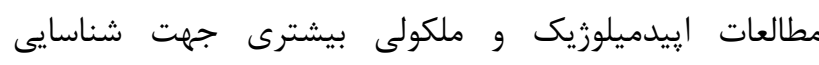
خصوصيات اين انگل در ايران ضرورى به نظر مىرسد.

8. Taylor MA, Coop RL, Wall RL. Veterinary parasitology. 3rd ed. United Kingdom: Blackwell Publishing Ltd.; 2007.

9. Cantacessi C, Gasser RB, Strube C, Schnieder T, Jex AR, Hall RS, et al. Deep insights into Dictyocaulusviviparus transcriptomes provide unique prospects for new drug targets and disease intervention. Biotechnol Adv. 2011; 29: 261-271. [DOI:10.1016/j.biotechadv.2010.11.005] [PMID] [PMCID]

10. Verstegen MW, Boon JH, van der Hel W, Yildiz K. Prevalence of lungworm infection in sheep and cattle in the Kirikkale province. Türk Parazitol Derg. 2006; 30: 190-193.

11. Panuska C. Lungworms of ruminants. Vet Clin N Am$\begin{array}{llll}\text { Food } \quad \text { A. 2006; } & \text { 22: }\end{array}$ [DOI:10.1016/j.cvfa.2006.06.002] [PMID]

12. Nashiruddullah N, Darzi MM, Shahardar RA, Kamil SA, Mir MS, Mansoor MM. Pathology of spontaneous Dictyocaulus sp. infection in hangul (Cervuselaphushanglu), sheep and goat. J Vet Parasitol. 2007; 21: 37-40.

13. Alipourazar M, Garedaghi Y, Hashemzadefarhang $\mathrm{H}$. Prevalence of cattle and buffalo lung-worm infestation in Tabriz city, Iran. Biol Forum. 2015; 7(1): 195-198.

14. Garedaghi Y, Rezaii saber AP, Naghizadeh A, Nazeri M. Survey on prevalence of sheep and goats lungworms in Tabriz abattoir, Iran. J Anim Vet Adv. 2011; 10(11): 1460-1461. [DOI:10.3923/javaa.2011.1460.1461]

15. Nematollahi A, Moghaddam G. A survey on annual infestation of sheepwith lungworms based on fecal test and slaughter house study in Tabriz. J Vet Res. 2009; 64(4): 339-342.

16. Sikandar A, Cheema AH, Younus M, Aslam A, Zaman MA, Rehman T. Histopathological and serological studies 
on paratuberculosis in cattle and buffaloes. Pak Vet $\mathrm{J}$. 2012; 32: 547- 551 .

17. Jung M, Jung BG, Cha SB, Shin MK, Lee WJ, Shin SW, et al. The effects of germanium biotite supplement as a prophylactic agent against respiratory infection in calves. Pak Vet J. 2012; 32: 319-324.

18. Alasaad S, Morrondo P, Dacal-Rivas V, Soriguer RC, Granados JE, Serrano E, et al. Bronchopulmonary nematode infection of Capra pyrenaicain the Sierra Nevada massif, Spain. Vet Parasitol. 2009; 164: 340-343. [DOI:10.1016/j.vetpar.2009.06.019] [PMID]

19. Bennema SC, Vercruysse J, Morgan E, Stafford K, Hoglund J, Demeler J, et al. Epidemiology and risk factors for exposure to gastrointestinal nematodes in dairy herds in northwestern Europé. Vet Parasitol. 2010; 173: $247-$ 254. [DOI:10.1016/j.vetpar.2010.07.002] [PMID]

20. Addis M, Fromsa A, Ebuy Y. Study on the prevalence of lungworm infection in small ruminants in Gondar town, Ethiopia. Vet Res. 2011; 4: 85-89. [DOI:10.3923/javaa.2011.1683.1687]

21. Silva MCD, Barros RRD, Graca DL. Outbreak of dictyocaulosis in cattle in Santa Maria, RS, Brazil. Cienc Rural. 2005; 35: 629-632. [DOI:10.1590/S010384782005000300022]

22. Sharma RL, Dhar DN. Prevalence of Dictyocaulusviviparusinfection in Kashmir. Iranian J Parasitol. 1987; 11: 101-105.

23. Lat-Lat H, Sani RA, Hassan L, Sheikh-Omar AR, Jeyabalan S, Hishammfariz M, et al. Lungworm of cattle in Malaysia. Trop Biomed. 2010; 27: 236-240.

24. Murphy TM, Fahy KN, McAuliffe A, Forbes AB, Clegg TA, O Brien DJ. A study of helminth parasites in culled cows from Ireland. Prev Vet Med. 2006; 76: 1-10. [DOI:10.1016/j.prevetmed.2006.04.005] [PMID]

25. Schnieder T, Kaup FJ, Drommer W. Morphological investigations on the pathology of Dictyocaulusviviparusinfections in cattle. Parasitol Res. 1991; 77: 260-265. [DOI:10.1007/BF00930869] [PMID]

26. Hoglund J, Viring S, Tornqvist M. Seroprevalence of Dictyocaulusviviparusin first grazing season calves in Sweden. Vet Parasitol. 2004; 125: 343-435. [DOI:10.1016/j.vetpar.2004.07.018] [PMID]

27. Divina BP, Wilhelmsson E, Mattsson JG, Waller P, Hoglund J. Identification of Dictyocaulus spp. in ruminants by morphological and molecular analyses. Parasitol. 2000; 121: 193-201. [DOI:10.1017/S0031182099006162] [PMID]

28. Pybus MJ. Survey of hepatic and pulmonary helminths of wild cervids in Alberta. Canadian. J Wildlife Dis. 1990; 26: 453-459. [DOI:10.7589/0090-3558-26.4.453] [PMID]
29. Strube C. Parasitic bronchitis in cattle - new chances for prevention of a continuous problem? Tieraerztl Umsch. 2012; 67: 387-394.

30. Holzhauer M, van Schaik G, Saatkamp HW, Ploeger HW. Lungworm outbreaks in adult dairy cows: estimating economic losses and lessons to be learned. Vet Record. 2011; 169: 494-502. [DOI:10.1136/vr.d4736] [PMID]

31. Ranganathan S, Nagaraj SH, Hu M, Strube C, Schnieder T, Gasser RB. A transcriptomic analysis of the adult stage of the bovine lungworm, Dictyocaulusviviparus. BMC Genom. 2007; 8: 311-315. [DOI:10.1186/1471-2164-8311] [PMID] [PMCID]

32. Bancroft JD, Marilyn G. Theory and practice of histological techniques. 6th ed. United Kingdom: Elsevier-Health Sciences Division; 2007. 